\title{
RELATIONSHIP BETWEEN PGE AND PGM IN THE BUSHVELD COMPLEX
}

\author{
R. GRANT CAWTHORN ${ }^{\S}$ \\ Department of Geology, University of the Witwatersrand, PO Wits, 2050, South Africa \\ Christopher A. LEE ${ }^{\mathbb{I I}}$ \\ Anglo Platinum Geology Department, PO Box 62179, Marshalltown, 2107, South Africa \\ ROBERT P. SCHOUWSTRA \\ Anglo Platinum Research Centre, PO Box 6540, Homestead, 1412, South Africa
}

PETER MELLOWSHIP

Impala Platinum Mines, PO Box 5683, Rustenburg, 0300, South Africa

\begin{abstract}
The abundances of the platinum-group elements (PGE), and their relative proportions, are summarized for all the mines exploiting the Merensky Reef on both western and eastern limbs of the Bushveld Complex, in South Africa. Grades for the mined reef interval are uniform over $100 \mathrm{~km}$ of strike length, at $5-7 \mathrm{~g} / \mathrm{t}$, except for Union mine, where it is currently $8 \mathrm{~g} / \mathrm{t}$. The relative proportions of the various PGE are extremely constant over this same distance. In contrast, the platinum-group minerals (PGM) vary enormously. On a regional scale around the western limb, the mineralogy ranges from alloy-dominated in the northwest to sulfide- or telluride-arsenide-dominant in the southeast. Local features that are important in terms of mining are potholes and discordant ultramafic bodies. Comparative studies of the PGE from close to and within such structures again show constant absolute and relative abundances. Limited data on the PGE from PGE-mineralized pipes (Onverwacht, Mooihoek and Driekop) suggest that they are Pt-dominated, and have a totally different relative pattern of distribution of the PGE than that in the stratiform mineralization. The PGM in the vicinity of these pipes also tends to be dominated by alloys, and in potholes by alloys and tellurides and arsenides. Hence, on both a regional scale and very local scale associated with disturbances in the reef, there is a dichotomy between the constancy of the PGE and the variability of the PGM. These observations suggest that the primary mechanism concentrating the PGE is a first-order process, and that the evolution of the PGM is the result of secondary processes related to cooling, local changes in $f\left(\mathrm{~S}_{2}\right)$ in the crystallization environment, and subsolidus re-equilibration. The debate as to whether the PGE are derived by fluid scavenging of a footwall succession or have accumulated from supernatant magma is reexamined, and unresolved problems pertaining to both processes are highlighted.
\end{abstract}

Keywords: Bushveld Complex, platinum-group elements, platinum-group mineralogy, Merensky Reef, potholes, pipes, mineralization, South Africa.

\section{SOMMAIRE}

Le niveau de concentration des éléments du groupe du platine (EGP), ainsi que leurs proportions relatives, sont examinés pour toutes les mines exploitant le banc de Merensky, dans les secteurs ouest et est du complexe de Bushveld, en Afrique du Sud. Les teneurs des sections exploitées de ce banc sont uniformes, entre 5 et $7 \mathrm{~g} / \mathrm{t}$, sur une distance de $100 \mathrm{~km}$, sauf à la mine Union, où la teneur est présentement $8 \mathrm{~g} / \mathrm{t}$. Les proportions relatives des EGP sont d'une constance frappante sur cette distance. En revanche, les assemblages de minéraux du groupe du platine varient énormément. Sur une échelle régionale autour du secteur ouest, ces minéraux vont d'alliages dans le nord-ouest aux minéraux sulfurés ou bien aux tellurures et arséniures vers le sud-est. Les "nidsde-poule" et les venues ultramafiques discordantes sont des accidents locaux qui exercent une influence sur les activités minières. Des études comparatives des EGP près de et à l'intérieur de ces structures montrent de nouveau que les abondances absolues et relatives sont constantes. Des données limitées sont disponibles pour les pipes minéralisées en EGP (Onverwacht, Mooihoek et Driekop). Ces structures sont à dominance de Pt, avec une distribution relative des EGP totalement différente que dans la minéralisation stratiforme. Les minéraux du groupe du platine près de ces pipes sont surtout des alliages, et dans les "nids-de-

\$ E-mail address: 065rgc@cosmos.wits.ac.za

II Present address: PO Box 68108, Bryanston 2021, South Africa 
poule", surtout des alliages, tellurures et arséniures. Donc, sur une échelle régionale aussi bien que sur une échelle très locale, près des accidents dans le banc de Merensky, la constance des EGP contraste avec la variabilité dans leur expression minéralogique. Ces observations font penser le mécanisme d'accumulation des EGP était de premier ordre, tandis que l'évolution des minéraux porteurs des éléments du groupe du platine résulterait de processus secondaires liés au refroidissement, aux changements locaux en $f\left(\mathbf{S}_{2}\right)$ dans le milieu de cristallisation, et au ré-équilibrage subsolidus. Les EGP ont-ils été extraits d'une succession de cumulats inférieurs ou bien accumulés à partir d'un magma susjacent? Les aspects non résolus de ce débat sont mis en relief.

(Traduit par la Rédaction)

Mots-clés: complexe de Bushveld, éléments du groupe du platine, minéraux du groupe du platine, banc de Merensky, "nids-depoule", pipes, minéralisation, Afrique du Sud.

\section{INTRODUCTION}

The Bushveld Complex (Fig. 1) hosts over half of the world's platinum-group element (PGE) reserves and resources (Cawthorn 1999a), and thus has had a major influence on the evolution of ideas on the genesis of such deposits. The PGE are hosted in three distinct layers (Lee 1996). The Merensky Reef and the Upper Group 2 (UG2) Chromitite, both from the upper part of the Critical Zone, occur in both the western and eastern limbs (Fig. 2). The Platreef (Fig. 2), north of Potgietersrus, occurs at the base of the Main Zone in the northern limb. It is much thicker than the Merensky Reef, and is complicated by interaction with sedimentary and granitic floor-rocks (White 1994). There is no significant Critical Zone or Lower Zone developed in the complex north of Potgietersrus, but possible correlatives of the Lower Zone exist as satellite bodies of pyroxenite and harzburgite in the immediate floor. South of Potgietersrus, Lower and Critical Zone rocks do occur, and a poorly mineralized possible equivalent of the Merensky Reef may be present (see Fig. 1). The occurrence of Pt in discordant pipes at Driekop, Mooihoek and Onverwacht in the eastern limb (Fig. 1) has received much attention, possibly because they were the sites of the first mining activity in 1925 (Wagner 1929). However, the largest and richest pipe (Onverwacht) produced only $1140 \mathrm{~kg}$ Pt at an average grade of $7 \mathrm{~g} / \mathrm{t}$ (Edwards \& Silk 1987).

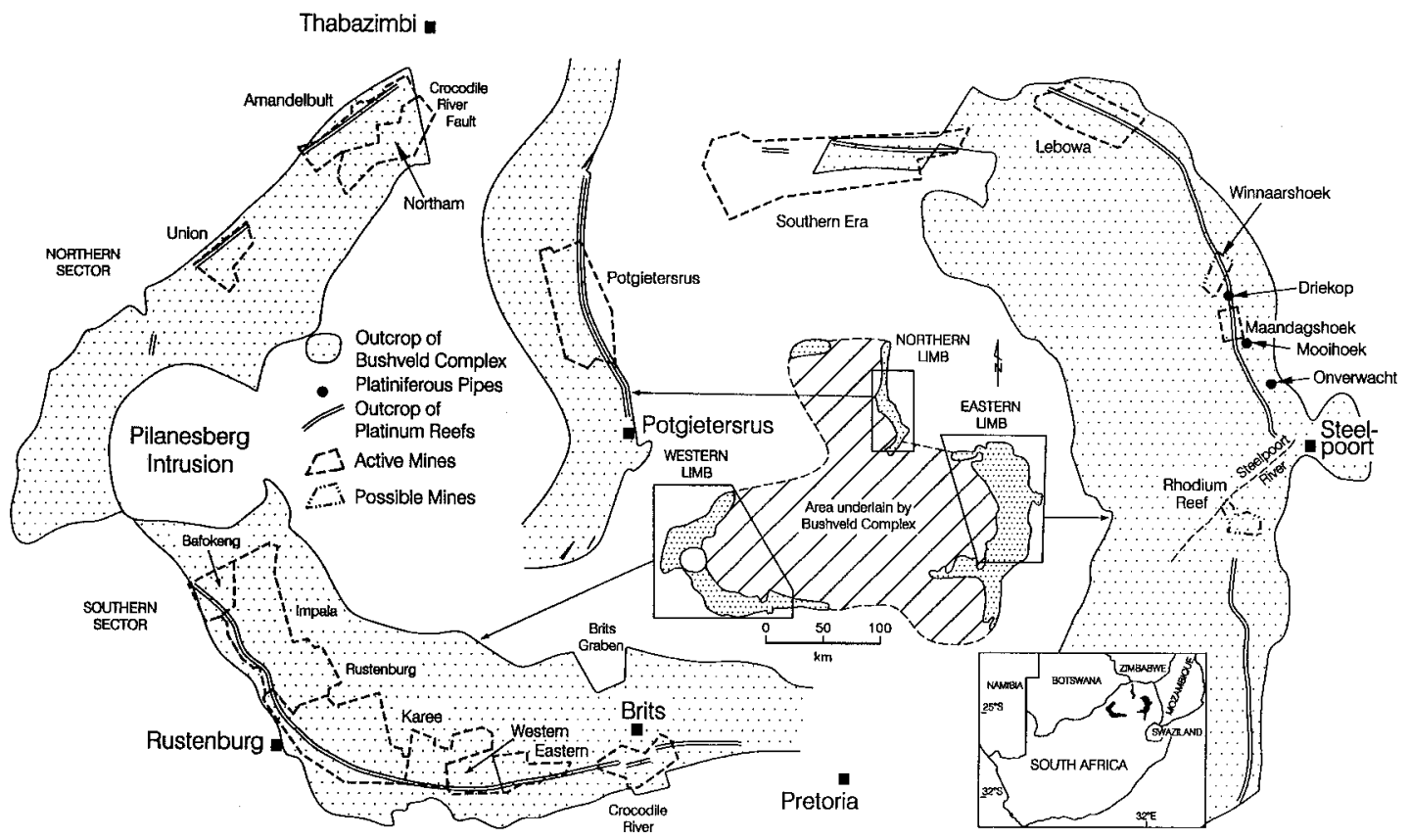

FIG. 1. General map of the Bushveld Complex (center), with different limbs (exploded views) showing active and proposed mines on Merensky or UG2 chromitite reefs (or both). PGE reefs are shown as a double line. The platiniferous pipes also are shown. 


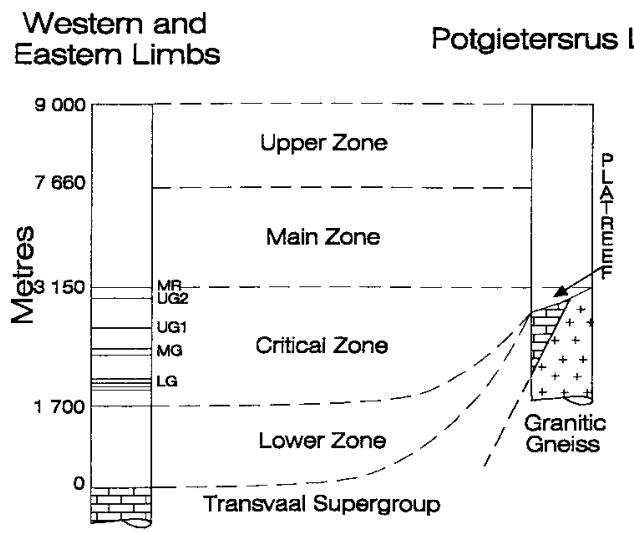

FIG. 2. Simplified stratigraphy of the eastern and western limbs (combined), showing the locations of chromitite layers of the lower, middle and upper groups (LG, MG, and UG, respectively) and Merensky Reef (MR), contrasted with the Potgietersrus limb, which contains the Platreef north of Potgietersrus (White 1994). The Lower Zone may be represented in the area north of Potgietersrus by satellite bodies intruded into the basement granitic gneiss (van der Merwe 1976).

Several quantitative studies have been presented containing information on the various platinum-group minerals (PGM) present in the Merensky Reef (e.g., Brynard et al. 1976, Vermaak \& Hendricks 1976, Kinloch 1982, Mostert et al. 1982, Peyerl 1982, Kinloch \& Peyerl 1990, Schouwstra et al. 2000), but fewer studies of the UG2 Chromitite are available (Kinloch 1982, McLaren \& De Villiers 1982; see summary by Penberthy \& Merkle 1999) and the Platreef Reef. Until recently, details of PGE grades and relative proportions of PGE for all the individual mines were not easily available. Generalized data were presented long ago (e.g., Naldrett \& Cabri 1976, Naldrett 1981), and data on single profiles or limited samples have been presented (Lee 1983), but comprehensive information from all the different mines has not been accessible. As a result of the requirements for reporting on international stock exchanges, for the last two or three years, mining companies have made such information more readily available in annual company reports and statements. Hence, it is now possible to make a quantitative comparison of PGE and PGM contents on individual mines and regionally throughout the entire Bushveld Complex. It is the purpose of this contribution to summarize such information, and to offer some speculations on the implications for the origin and evolution of these deposits. Most of the information is available for the Merensky Reef in the western Bushveld; most emphasis thus will be placed on this reef.
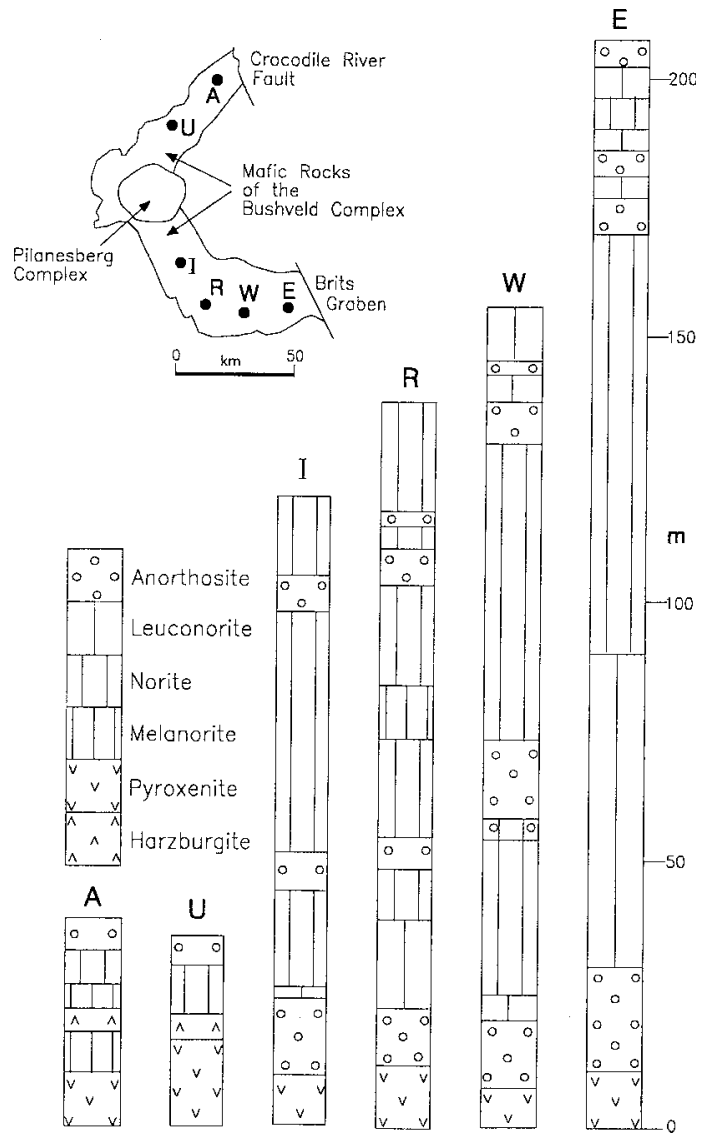

FIG. 3. Geological map of the western Bushveld Complex and vertical sections through the UG2 cyclic unit from Amandelbult (A), Union (U), Impala (I), Rustenburg (R), Western (W) and Eastern (E) platinum mines (compiled from Eales et al. 1993). The UG2 chromitite layer forms the base of each of these sections, and the lower chromite to the Merensky Reef, the top.

\section{Geology of PGE-Mineralized Layers}

The Upper Critical Zone of the Bushveld Complex can be subdivided into a number of cyclic units that ideally display a sequence from chromitite through pyroxenite and occasionally harzburgite, to norite and anorthosite. Some cycles may be incomplete, others vary laterally in thickness of individual layers. For example, the UG2 cyclic unit varies from 40 to over 200 $\mathrm{m}$ in thickness, and from dominantly ultramafic to leucocratic, from northwest to southeast in the western Bushveld (Fig. 3). The thickest cycle may exceed 200 $\mathrm{m}$, whereas the thinnest, the Merensky cyclic unit, may be on the order of $10 \mathrm{~m}$ (Lee 1996, Viljoen \& 
Schurmann 1998). All the chromitite layers contain a high PGE content (Fig. 4), ranging from 0.2 to $6.0 \mathrm{~g} / \mathrm{t}$ (summarized in Cawthorn 1999a).

The Merensky Reef is a mining term, which refers to the mining width of about $90 \mathrm{~cm}$ that defines the best grade of PGE mineralization and occurs close to the base of the Merensky cyclic unit. Lithologically, the reef can be very variable (Vermaak 1976, Viljoen \& Schurmann 1998). Generally, the mineralization straddles the uppermost portion of the anorthosite forming the top of the underlying cyclic unit and the ultramafic rocks forming the base of the Merensky cyclic unit. However, details of the sequences vary enormously, even across a single mine. Typical and simplified sections of the reef around the Bushveld Complex are shown in Figure 5, which also includes a qualitative profile of the vertical

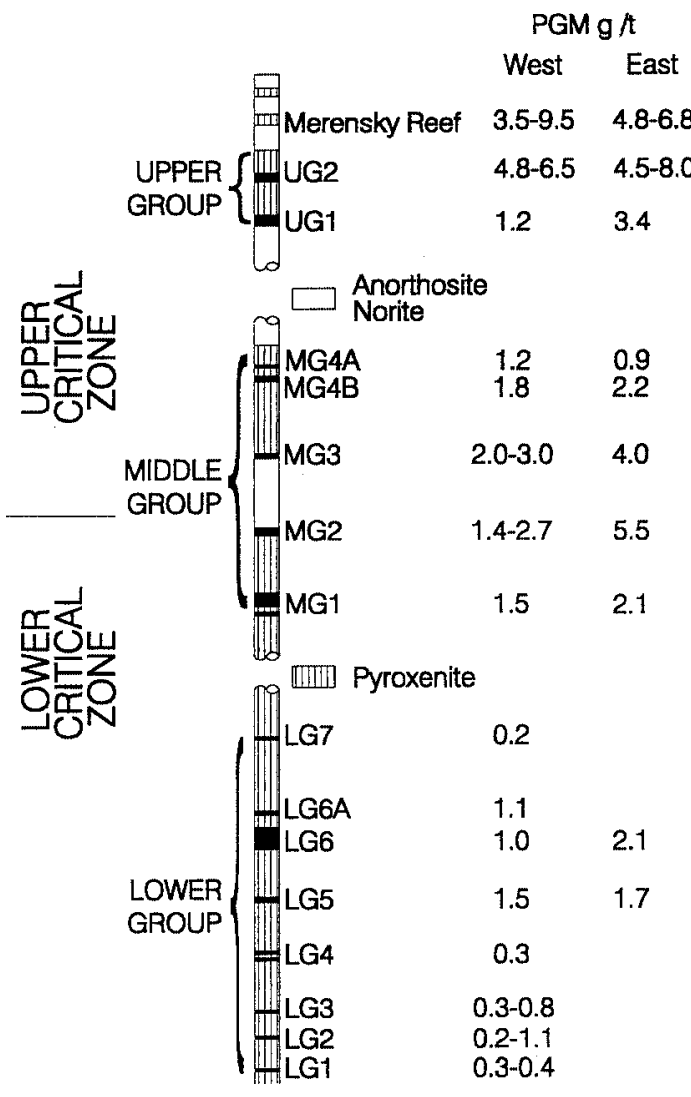

FIG. 4. Stratigraphic section (not drawn to scale) of the chromitite layers and their PGE contents, based on data from Lee \& Tredoux (1986), Lee \& Parry (1988), Scoon \& Teigler (1994), von Gruenewaldt \& Merkle (1995) and von Gruenewaldt et al. (1986). Data are based on single analyses or averages of very few analyses, and so should not be considered quantitatively representative of the layers. distribution of the PGE grades. The simplest sequence is shown by that in the northern half of the Impala mine, where a footwall anorthosite is overlain by a one-cmthick layer of chromitite and a feldspathic pyroxenite. The PGE are distributed approximately symmetrically about, and highly concentrated in, the chromitite layer. In the south of the mine and in most of the Rustenburg mine, the reef includes a layer of pegmatitic pyroxenite overlying the basal chromitite (Fig. 5) and commonly contains an upper and intervening thin layers of chromitite (Rustenburg narrow reef). The mineralization is concentrated, but by no means confined to, the interval between the top and bottom layers of chromitite. Traced further east to the Western mine (and the widereef facies at Rustenburg mine), the reef widens, the interval between the chromitite layers becomes generally pyroxenitic with only thin layers of pegmatitic pyroxenite near the chromitite layers. The grade is highest near the upper chromitite layer, although some enrichment is recorded in the lower one. The spacing between the upper and lower chromitite layers may reach $7 \mathrm{~m}$ (Brynard et al. 1976). At the Impala, Rustenburg and Karee mines, a significant portion of the ore is extracted from the anorthositic footwall, but where the separation between the lower and upper chromitite layers increases, the PGE content in the footwall anorthosite decreases (Fig. 5), i.e., mineralization tends to be concentrated near the upper chromitite layer where more than one chromitite layer is present. Traced from the Impala mine to the north (Union mine), a similar change to that noted toward the east can be recognized in that there are at least two chromitite layers, and the PGE grades are highest near the upper one.

In the eastern limb, the section from the mine being brought into production on the farm Winnaarshoek (Fig. 1) has similarities with the Rustenburg wide reef (Fig. 5), except that there are no pegmatitic rocks associated with the main mineralization, which occurs near the uppermost chromitite enclosed in pyroxenite. A pegmatitic pyroxenite occurs in the footwall succession to the main mineralization, but is poorly mineralized. The mineralization at the Lebowa mine (also known as Atok mine) has similarities with that at Winnaarshoek in that the main mineralization occurs in pyroxenite between two layers of chromitite that lie above the pegmatitic pyroxenite layer.

The Merensky Reef and its host rocks are not always perfectly concordant with the underlying succession. One important feature, of major concern for mining, is the presence of potholes (Fig. 6). These are subcircular structures in plan where the reef plunges, cutting its footwall stratigraphy (Lee 1996). The depth and lateral extent can be very variable, from $1-3 \mathrm{~m}$ to $100 \mathrm{~m}$ deep, and from $10 \mathrm{~m}$ to one $\mathrm{km}$ across. The laterally most extensive potholes occur in the north (Viljoen et al. 1986a, b) at the Amandelbult, Union and Northam mines (Viring \& Cowell 1999), where much of the mining takes place on what is called "regional pothole reef", 

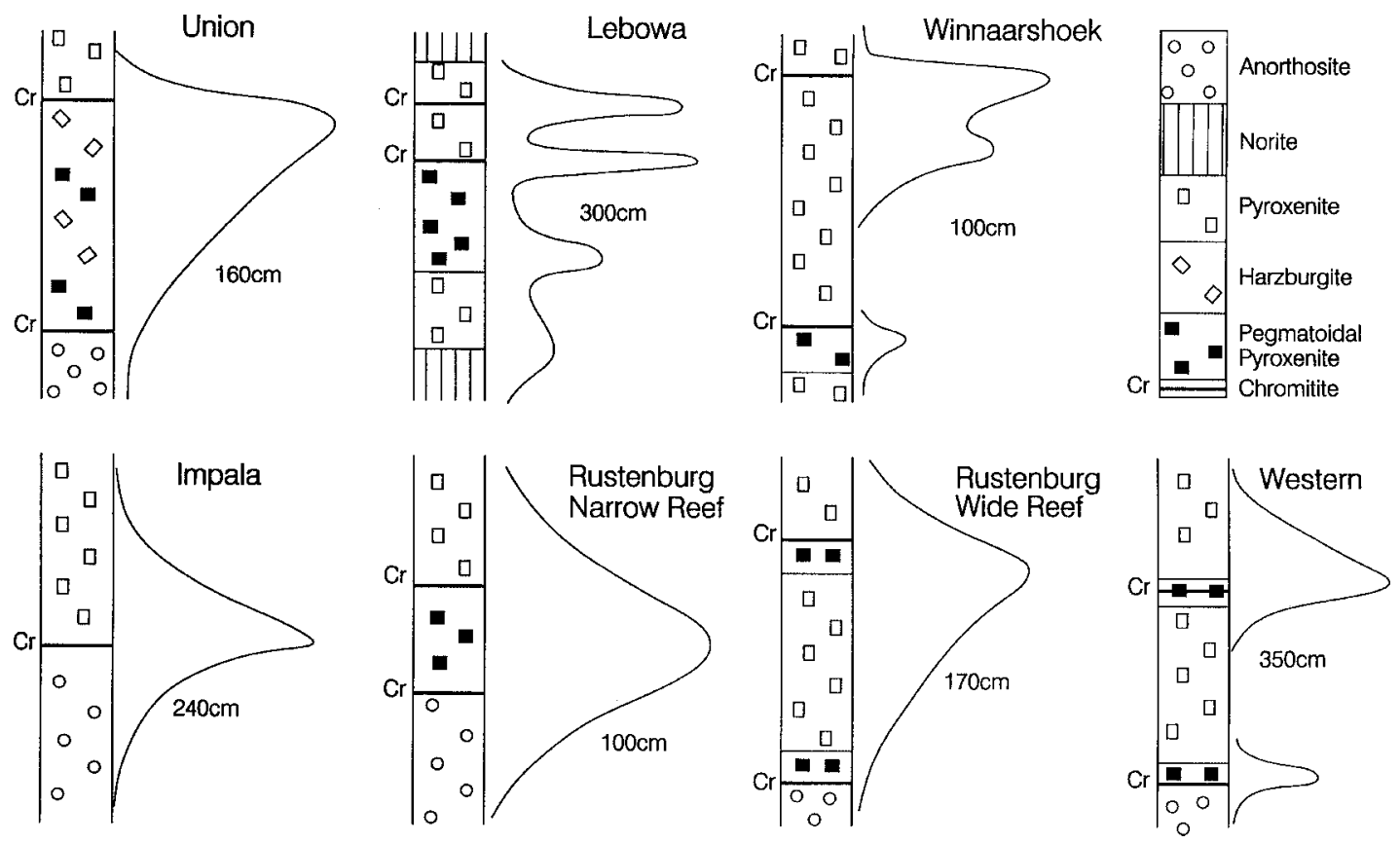

FIG. 5. Typical sections and thicknesses through the Merensky Reef at several mines (data from Mossam 1986, Viljoen et al. 1986a, b, Viljoen \& Schurmann 1998, Hochreiter 2000), none of whom provided a quantitative scale.

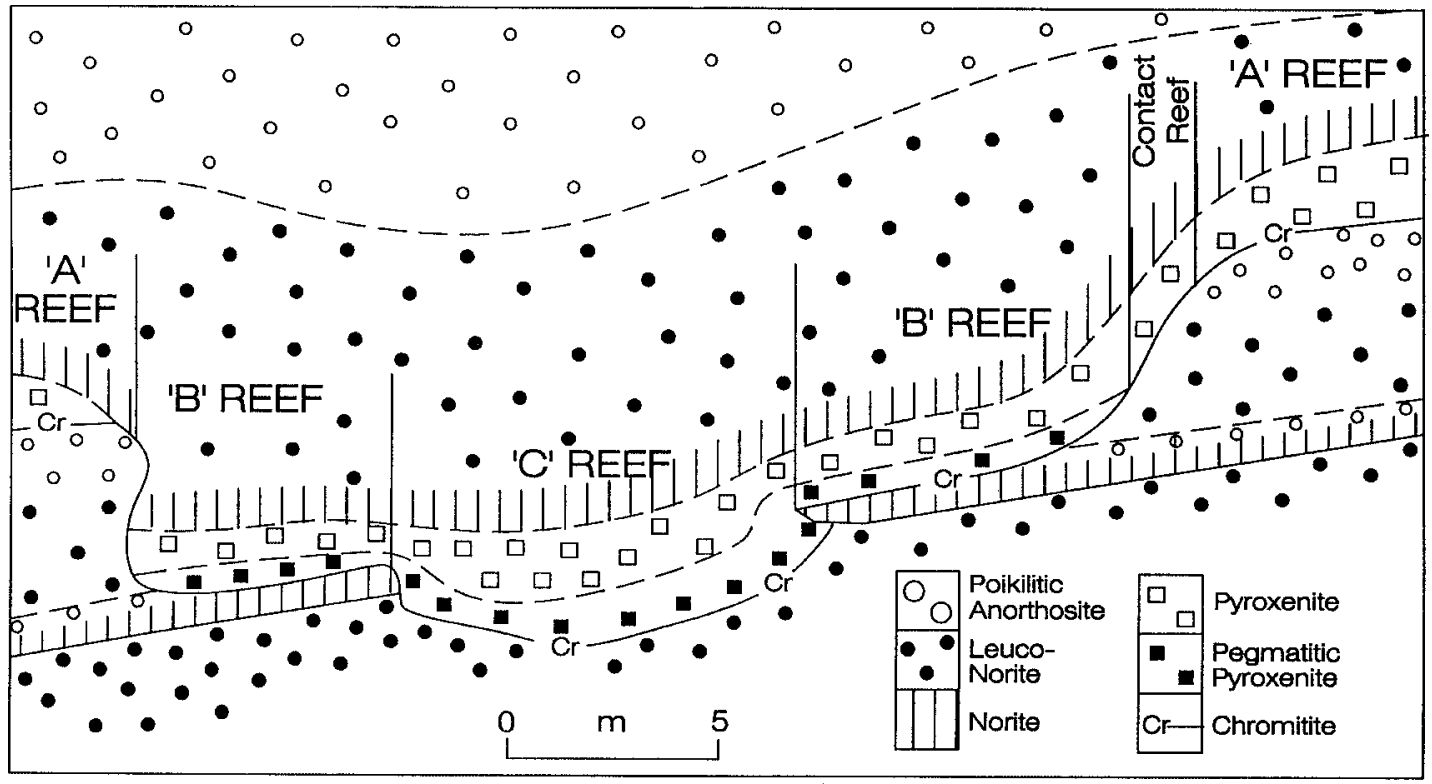

FIG. 6. Cross-section of a relatively small pothole, showing the location of contact reef where mineralization is almost totally confined to the chromitite layer, and hence total PGE content is low (Leeb-du Toit 1986). 
the down-dip limits of which have yet to be identified. The cross-sectional geometry of a typical pothole is shown in Figure 6. At the Impala mine, the reef at normal elevation is called A reef, where it occurs in a shallow depression it is called B reef, and in deeper potholes it is called C reef (Fig. 6). Their distribution is variable, but occupy on average about $20 \%$ of the orebody at the Impala mine, and somewhat less at the Rustenburg mine. From a detailed study of the distribution of potholes at the Western Platinum mine, Carr et al. (1994) suggested that they occur in elongate clusters aligned parallel to strike. Where infrequent or small, these potholes are not amenable to mining, but provided they have a planar base, they are considered economic to mine despite the extra development required to access the reef at these lower levels.

Many descriptions of the Upper Group 2 (UG2) chromitite layer and its host have been published (Gain 1985, Hiemstra 1985, 1986, Viljoen \& Schurmann 1998, Lomberg et al. 1999, Penberthy et al. 2000). It ranges from 30 to $120 \mathrm{~cm}$ thick, but is typically about $80 \mathrm{~cm}$ thick. Its footwall is usually a thin pegmatitic feldspathic pyroxenite, although it may be absent. Below this layer, from the Rasimone-Bafokeng mine to the Eastern platinum mine (Fig. 1) lies an anorthosite or norite, being the top of the UG1 cyclic unit. At the Union and Amandelbult mines, the footwall is pyroxenite. Everywhere the hanging wall of the UG2 chromitite layer is pyroxenitic, but with olivine in the northwestern limb (Viljoen et al. 1986a, Cawthorn \& Barry 1992). Multiple, thin, commonly bifurcating layers of chromitite exist in the few meters above the UG2, and they have been well documented at the Karee mine (Davey 1992). The distribution of PGE within the UG2 is extremely variable vertically, but laterally shows a similar pattern (Gain 1985, Hiemstra 1985, 1986, Davey 1992, Viljoen \& Schurmann 1998, Penberthy \& Merkle 1999). There is a very high concentration of the PGE in the bottommost $20 \mathrm{~cm}$, lower values in the middle, and high values close to the top. Other geochemical and textural differences exist, from which it could be inferred that the layer comprises at least two distinct, superposed layers (Lee 1996). Lenses of pyroxenite up to many meters in length occur within the layer, in some cases being concentrated at very specific horizons, and indicate that discrete thinner layers of chromitite may be superposed (Lee 1996). The hanging wall and footwall silicate-rich rocks are barren of PGE, but where the pegmatitic pyroxenite contains chromitite schlieren, some PGE may be present (Viljoen \& Schurmann 1998).

Potholes are also encountered on the UG2 chromitite (Hahn \& Ovendale 1994, Lomberg et al. 1999). However, in detail they have a morphology slightly different from that of the Merensky potholes. They rarely have a planar base, and so are usually not mined. They tend to have smaller area-to-depth ratios. Where the normal reef is underlain by pegmatitic pyroxenite, the UG2 potholes usually cut through this layer and lie on the underlying anorthosite. The UG2 chromitite layer usually thins markedly within the pothole, unlike the Merensky Reef in potholes, where it and the overlying layers are thicker than elsewhere.

\section{PGE Content of the Merensky Reef}

The Merensky Reef can be traced in the western limb along an exposed strike length of nearly $120 \mathrm{~km}$ (Fig. $1)$. There are three interruptions of the reef, the Pilanesberg intrusion (a younger syenite-dominant complex), and two areas to the north of Pilanesberg where the rocks of the Critical Zone have been displaced by the cross-cutting relations of the overlying layers of the Main and Upper zones. In total, about $50 \mathrm{~km}$ of strike length has been eliminated, although highly disrupted remnants of the reef may have been preserved to the west of Pilanesberg (Vermaak 1970).

The average grade over a mining thickness of about $90 \mathrm{~cm}$, the actual thickness and grade of the best mineralization, and relative proportions of the PGE of the Merensky Reef for all the major mines around the Bushveld Complex have been compiled in Table 1 and Figures 7 and 8. The data are taken from annual reports and summary publications of mining companies (Vermaak 1995, Vermaak \& van der Merwe 1999). The data are the average results of huge numbers of routine analyses performed during normal mining activities and from advanced drilling and exploration boreholes. Samples are usually $10 \mathrm{~cm}$ thick, but vary to accommodate lithological changes. The total PGE content (which may exclude Ir or Os or both) usually is determined in assays; a very much smaller set of samples is analyzed for individual PGE. These figures refer to in situ grade of a mining width. Two examples of actual data on in-

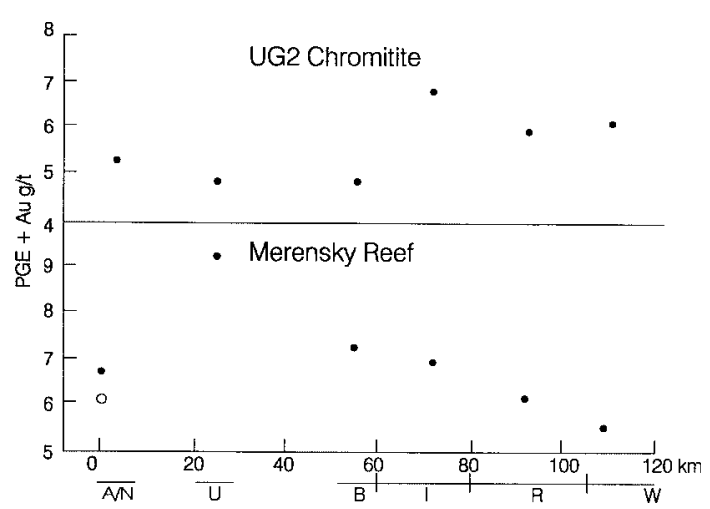

FIG. 7. PGE grades for the Merensky Reef and UG2 chromitite at all mines in the western limb. Abbreviations as in Figure 3; Bafokeng-Rasimone (B), Northam (N). The open circle refers to the Northam mine. Data are taken from annual reports of mining companies. 
dividual analyzed sections are given below. The thickness of the zone of high-grade mineralization may differ from the mining width; such grades thus may be different from reported grades (Table 1). For example, at the Union mine, the mineralized reef is $130 \mathrm{~cm}$ wide and averages $7.4 \mathrm{~g} / \mathrm{t} \mathrm{PGE}$, whereas over the mining width, the grade is slightly higher at $9.2 \mathrm{~g} / \mathrm{t}$. Conversely, the narrow reef at the Rustenburg mine has a high grade of $8.5 \mathrm{~g} / \mathrm{t}$, but over a width of less than the mining width, and so relatively lower-grade ore also has to be extracted. The difficulty is quoting a grade for the reef is illustrated by the fact that the grade of the reserves at the Union mine was quoted as $9.2 \mathrm{~g} / \mathrm{t}$ in the 1999 annual company report and as $7.9 \mathrm{~g} / \mathrm{t}$ in the latest report. Thus the precision of the data in Table 1 is possibly only within $1 \mathrm{~g} / \mathrm{t}$.

The most comprehensive data come from the western Bushveld, since most of the active mines are situated there. There is only one active mine on the eastern limb, although there is currently considerable exploration in the region, mainly focused on the UG2 chromitite layer. The reason for the preferential concentration of mines in the west is the better infrastructure compared to the east, primarily availability of water and human resources, and not the variation in PGE grade. The variation in grade and, especially, the relative proportions of the PGE of the Merensky Reef across the entire intrusion are relatively constant (Table 1). The Union mine is an exception in having higher-than-average grades and thicknesses. The veracity of such databases is crosschecked by monitoring grades and recoveries throughout the mining and extraction processes.

\section{PGM of the Merensky ReEF}

The numerous studies of the PGM of the Merensky Reef (e.g., Brynard et al. 1976, Vermaak \& Hendricks 1976, Kinloch 1982, Mostert et al. 1982, Peyerl 1982,

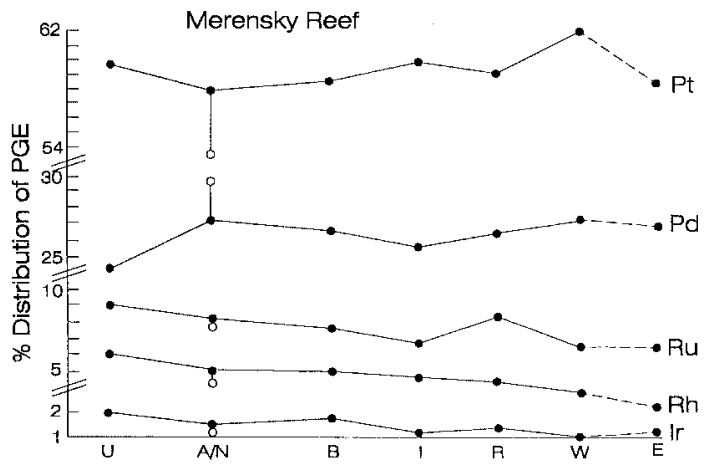

FIG. 8. PGE proportions for the Merensky Reef at all mines in the western limb. Abbreviations as in Figure 7. Data from annual reports of mining companies.
Kinloch \& Peyerl 1990, Schouwstra et al. 2000) include a wide range of minerals, some of which are extremely rare. Also, because of their scarcity even in the most heavily mineralized samples, it is difficult to know whether variations in reported proportions from different populations of samples are real or whether they are simply the result of the very small population of PGM in any set of sections studied under the microscope or scanning electron microscope. However, such data are crucial for effecting maximum metallurgical efficiency, and a very large mineralogical database has been accumulated for this purpose by the mining companies, part of which has been published (e.g., Vermaak \& Hendricks 1976, Peyerl 1982, Kinloch 1982, Kinloch \& Peyerl 1990, Schouwstra et al. 2000). This information, and further unpublished data, are summarized here with permission of Anglo American Platinum and Impala Platinum Mines.

The reef consists of $2-4 \%$ sulfide, the rest being mainly primary orthopyroxene, clinopyroxene, olivine, plagioclase and chromite, with minor proportions of late-stage and secondary minerals, including phlogopite, quartz, orthoclase, apatite, zircon, tremolite, talc and serpentine (Lee 1996). Of metallurgical significance is the association of the PGM, which may occur with sulfide or both primary and secondary silicate phases, and they may be enclosed within grains or on grain boundaries, but for the present purposes such textural infor-

TABLE 1. PGE GRADES AND PROPORTIONS FOR THE MERENSKY REEF AT VARIOUS MINES IN THE BUSHVELD COMPLEX

\begin{tabular}{|c|c|c|c|c|c|c|c|c|}
\hline Mine & $\begin{array}{c}\text { PGE } \\
(\mathrm{g} / \mathrm{t}) \\
\text { mining } \\
\text { width }\end{array}$ & $\begin{array}{c}\text { PGE } \\
(\mathrm{g} / \mathrm{t}) \\
\text { best } \\
\text { grade }\end{array}$ & $\begin{array}{c}\text { Thick- } \\
\text { ness of } \\
\text { best } \\
\text { grade }\end{array}$ & P & \% & & & $\begin{array}{l}\text { Os } \\
\%\end{array}$ \\
\hline
\end{tabular}

\begin{tabular}{|c|c|c|c|c|c|c|c|c|c|}
\hline \multicolumn{10}{|c|}{ Western limb } \\
\hline Amandelbult & 6.7 & 7.9 & 100 & 58 & 28 & 7 & 4 & 1.5 & 1.0 \\
\hline Union & 9.2 & 7.4 & 130 & 59 & 24 & 8 & 5 & 1.8 & 1.0 \\
\hline Northam & 6.1 & & & 61 & 26 & 7 & 3 & 1.3 & 2.0 \\
\hline Bafokeng & 7.3 & & & & & & & & \\
\hline Impala & 6.8 & & & 59 & 27 & 7 & 5 & 1.7 & 1.4 \\
\hline Rustenburg & 6.9 & 8.5 & 40 & 59 & 27 & 8 & 4 & 1.3 & 0.9 \\
\hline Western & 5.6 & & & 62 & 28 & 6 & 3 & 1.0 & 0.3 \\
\hline \multicolumn{10}{|c|}{ Eastern limb } \\
\hline Messina & 4.9 & & & 48 & 41 & 5 & 3 & 2 & n.a. \\
\hline Lebowa & 5.9 & 6.8 & 65 & 61 & 25 & 8 & 4 & 1.3 & 1.0 \\
\hline Winnaarshoek & 5.9 & & & 54 & 30 & 6 & 3 & 1.4 & n.a. \\
\hline
\end{tabular}

Variations in total PGE content occur in different reports. Some data are for metal produced, others are based on proven reserves, and yet others include resources. In other cases, mine-head grade is reported, in others it is in situ content. Some company reports quote assays for 4 or 5 PGE (which may exclude $\mathrm{Ir}$ and $\mathrm{Os}$ ), and others include Au. The under-representation due to such omission is in the order of $5 \%$. Routine analyses for total PGE are by ICP. The averaging of large numbers of analytical results in this table, and the monitoring of recoveries through the production of pure metal, render these data more reliable than analyses of single profiles by more precise techniques. The first column of figures are for the mined width, which may include sections of lower-grade ore in thin reef situations or cut-off grades of 1-1.5 $\mathrm{g} / \mathrm{t}$ for thick reef. n.a.: no data available. 
mation is ignored. The estimated proportions of various PGM from the mines are compiled in Figure 9. In detail, there are large variations in such proportions, even on a local scale. Such variations have been related to potholes and discordant pipes, the nature of the footwall sequence and reef thickness (Kinloch \& Peyerl 1990). However, in general the gross variation among all the mines of the western limb can be summarized in Figure 9. The regional trend shows that to the north there is a preponderance of alloy phases, whereas to the south and east, sulfides and tellurides become more abundant.

Analysis of base-metal sulfides (BMS), mainly pyrrhotite, chalcopyrite and pentlandite, indicates low concentrations of PGE, but given their much greater abundance than the PGM, the contribution from these BMS to the total PGE content is significant (Ballhaus \& Ryan 1995).

\section{PGE AND PGM IN Potholes}

PGE data through pothole structures have not been previously published, although PGM data have been presented. The variation in grade across $\mathrm{A}$ and $\mathrm{C}$ reefs at the Impala mine is shown in Tables 2 and 3, and Figure 10. At the base of the A reef, there is a thin chromiterich unit carrying very high grades, with a tail both upward and downward, each being about one meter. The footwall is anorthosite, and the hanging wall is feldspathic pyroxenite. Unlike the reef at the Rustenburg mines, there is no pegmatitic pyroxenite facies in the reef at the northern half of the Impala mines, although it is present in the south of the property and in potholes even in the north (Leeb-du Toit 1986, Viljoen 1999). In the $\mathrm{C}$ reef, there is pegmatitic pyroxenite, which has been analyzed as a single sample (Table 3 ). It contains the highest grades, and also has a symmetrical tail above and below, although the grades in the footwall decrease more rapidly than below the normal A reef. If averaged over the normal mining width of $80 \mathrm{~cm}$, there is a slight increase in the overall grade in the $\mathrm{C}$ reef $(7.8 \mathrm{~g} / \mathrm{t})$ relative to the A reef $(5.9 \mathrm{~g} / \mathrm{t})$, and the total contained PGE over the analyzed interval is also higher; this situation is typical of many potholes at the Impala mine. We suggest that this slight enrichment results from the inward concentration of mineralization at the base of the pothole and not along the sloping edges. Along the sloping edges of potholes, only a very thin layer of chromitite, known as contact reef, is present, and its PGM are dominated by laurite, which is typically associated with chromite (Kinloch \& Peyerl 1990). This effect is shown in Figure 6. The relative proportions of the PGE in A, B and $\mathrm{C}$ reefs are shown in Figure 11, where they can be seen to be relatively uniform.

Excluding the atypical contact-reef margins, the PGM in pothole reef are dominated by Pt-Fe alloys and tellurides (Kinloch \& Peyerl 1990). At the Union and Amandelbult mines, normal reef also is dominated by $\mathrm{Pt}-\mathrm{Fe}$ alloys and tellurides, and so there is no fundamental difference in mineralogy between normal and pothole reef at these mines. However, at the Rustenburg and Impala mines, normal reef contains a high proportion of Pt and Pd sulfides. The change from sulfidedominant PGM in normal reef to Pt-Fe alloys and

TABLE 2. VARIATION IN PGE DISTRIBUTION BETWEEN NORMAL AND POTHOLE REEF AT THE IMPALA MINE

\begin{tabular}{lcccccc}
\hline Reef & Pt \% & Pd \% & Ru \% & Rh\% & Ir \% & Os \% \\
\hline A & 60.7 & 25.8 & 7.8 & 4.1 & 1.4 & n.a. \\
B & 58.8 & 27.7 & 8.2 & 3.8 & 1.5 & n.a. \\
C & 57.1 & 28.1 & 9.1 & 3.7 & 1.7 & n.a. \\
\hline
\end{tabular}

These results are based on multiple analyses of these reef sections accumulated during routine analyses by the Impala mine staff.

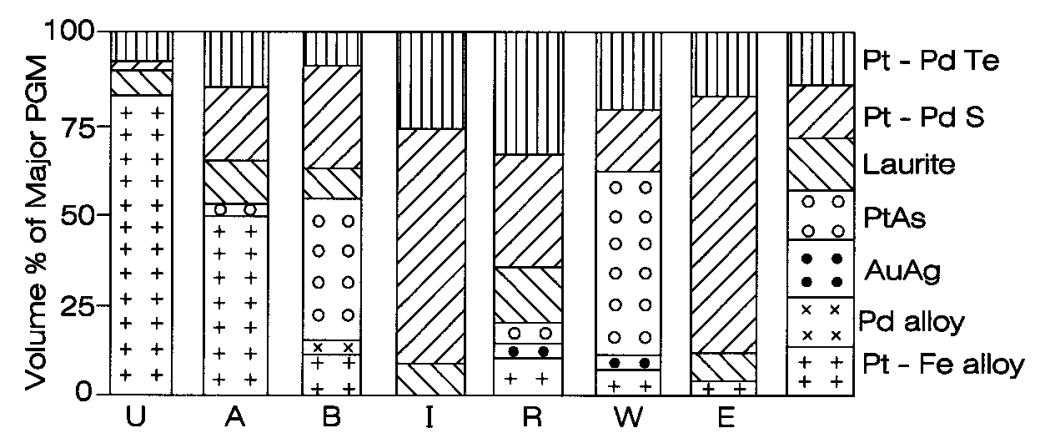

FIG. 9. PGM distribution for the Merensky Reef at all mines in the western limb, and the Lebowa mine in the eastern limb (denoted E). Other abbreviations as in Figures 3 and 7. Data from mining company reports, summarized by Schouwstra et al. (2000), and an unpublished report from Impala mine. 
tellurides in a pothole reef is abrupt and distinct (Fig. 11a), and these changes mirror those observed on a regional scale from Impala to Amandelbult mines (Fig. 11b). For simplicity of comparison, the minerals (in Fig. 11) have been divided into three groups, alloys (mainly $\mathrm{Pt}_{3} \mathrm{Fe}$ ), sulfides (mainly cooperite, braggite,

TABLE 3. TOTAL PGE CONTENT OF SECTIONS THROUGH NORMAL (A) AND POTHOLE (C) REEF AT THE IMPALA MINE

\begin{tabular}{|c|c|c|c|c|c|}
\hline $\begin{array}{c}\text { Thickness } \\
\text { in } \mathrm{cm}\end{array}$ & Rock type & $\begin{array}{c}\text { PGE } \\
\mathrm{g} / \mathrm{t}\end{array}$ & $\begin{array}{l}\text { Thickness } \\
\text { in } \mathrm{cm}\end{array}$ & Rack type & $\begin{array}{c}\text { PGE } \\
g / t\end{array}$ \\
\hline \multicolumn{3}{|c|}{ Normal (A) Reef } & \multicolumn{3}{|c|}{ Pothole (C) Reef } \\
\hline 10 & Pyroxenite & 0.40 & 10 & Pyroxenite & 0.13 \\
\hline 10 & Pyroxenite & 0.52 & 10 & Pyroxenite & 0.24 \\
\hline 10 & Pyroxenite & 0.97 & 10 & Pyroxenite & 0.63 \\
\hline 10 & Pyroxenite & 2.08 & 10 & Pyroxenite & 1.47 \\
\hline 10 & Pyroxenite & 4.52 & 10 & Pyroxenite & 3.44 \\
\hline 12 & Pyroxenite & 5.53 & 12 & Pyroxenite & 3.80 \\
\hline 3 & $\begin{array}{l}\text { Pegmatitic } \\
\text { Pyroxenite }\end{array}$ & 57.86 & 67 & $\begin{array}{l}\text { Pegmatitic } \\
\text { Pyroxenite }\end{array}$ & 10.2 \\
\hline \multicolumn{6}{|c|}{ Base of ultramafic rocks of the Merensky Cyclic Unit } \\
\hline 10 & Leuconorite & 7.19 & 12 & Leuconorite & 2,69 \\
\hline 10 & Leuconorite & 6.10 & 10 & Leuconorite & 2.35 \\
\hline 10 & Leuconorite & 4.22 & 10 & Leuconorite & 1.88 \\
\hline 10 & Leuconorite & 3.07 & 10 & Leuconorite & 1.45 \\
\hline 10 & Leuconorite & 2.35 & 10 & Leuconorite & 1.35 \\
\hline 10 & Leuconorite & 1.87 & 10 & Leuconorite & 1.11 \\
\hline 10 & Leuconorite & 1.43 & 10 & Leuconorite & 1.08 \\
\hline 10 & Leuconorite & 1.03 & 10 & Leuconorite & 0.65 \\
\hline 10 & Leuconorite & 0.66 & 10 & Leuconorite & 0.52 \\
\hline 10 & Leuconorite & 0.46 & 10 & Leuconorite & 0.43 \\
\hline 10 & Leuconorite & 0.34 & & & \\
\hline
\end{tabular}

Results of analyses of two sections through A (normal) and C (pothole) reef (not averages of larger database) laurite), and tellurides, bismuthides and arsenides. In conclusion, it appears that very local but dramatic changes in PGM can occur in potholes relative to normal reef, but the abundance and distribution of the PGE are not affected.

\section{PGE and PGM Associated with Discordant Pipes}

Of a large number of discordant ultramafic bodies that cut the layering, only three (Driekop, Mooihoek and Onverwacht) contained economic concentrations of PGE, and they were mined out by 1928 . All three occur to the north of Steelpoort in the eastern limb (Fig. 1). However, minor amounts of PGM are present in other pipes. There exist two settings of PGM occurrences in these pipes. In the three well-mineralized pipes, the core of the pipes contained economic mineralization over a considerable vertical extent $(>100 \mathrm{~m})$. In the case of other pipes that cut the Merensky and UG2 chromitite reefs, mineralization is found at the level of the original concordant mineralized layer, and probably represents replacement and recrystallization of the primary ore with minimal vertical displacement (Viljoen et al. 1986b). The relationship between the chromitite and PGE mineralization in normal reef and these replacement pyroxenite pipes is shown schematically in Figure 12. In the latter case, Kinloch \& Peyerl (1990) documented the predominance of $\mathrm{Pt}-\mathrm{Fe}$ alloy over laurite, sperrylite and tellurides.

No statistically reliable statement of relative abundances of PGM in the mineralized pipes has ever been made, and insufficient representative ore remains for further evaluation. However, the major minerals were sperrylite, Pt-Fe alloy, Pt metal, hollingworthite and irarsite, with an absence of sulfides (Kinloch \& Peyerl

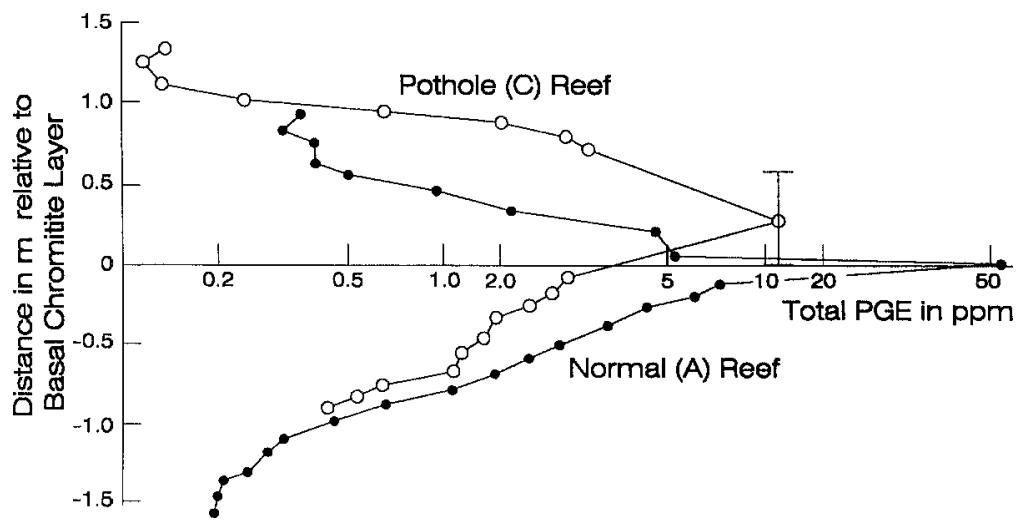

FIG. 10. Example of vertical distribution of the PGE from two sections across A (normal) and C (pothole) Merensky reef at the Impala mine, shown by solid and open symbols respectively. Continuous sampling every $10 \mathrm{~cm}$ is employed, except in the pothole reef, where the entire $60 \mathrm{~cm}$-thick pegmatitic pyroxenite is taken as a single sample. Note log scale for PGE content. Data given in Table 3. 

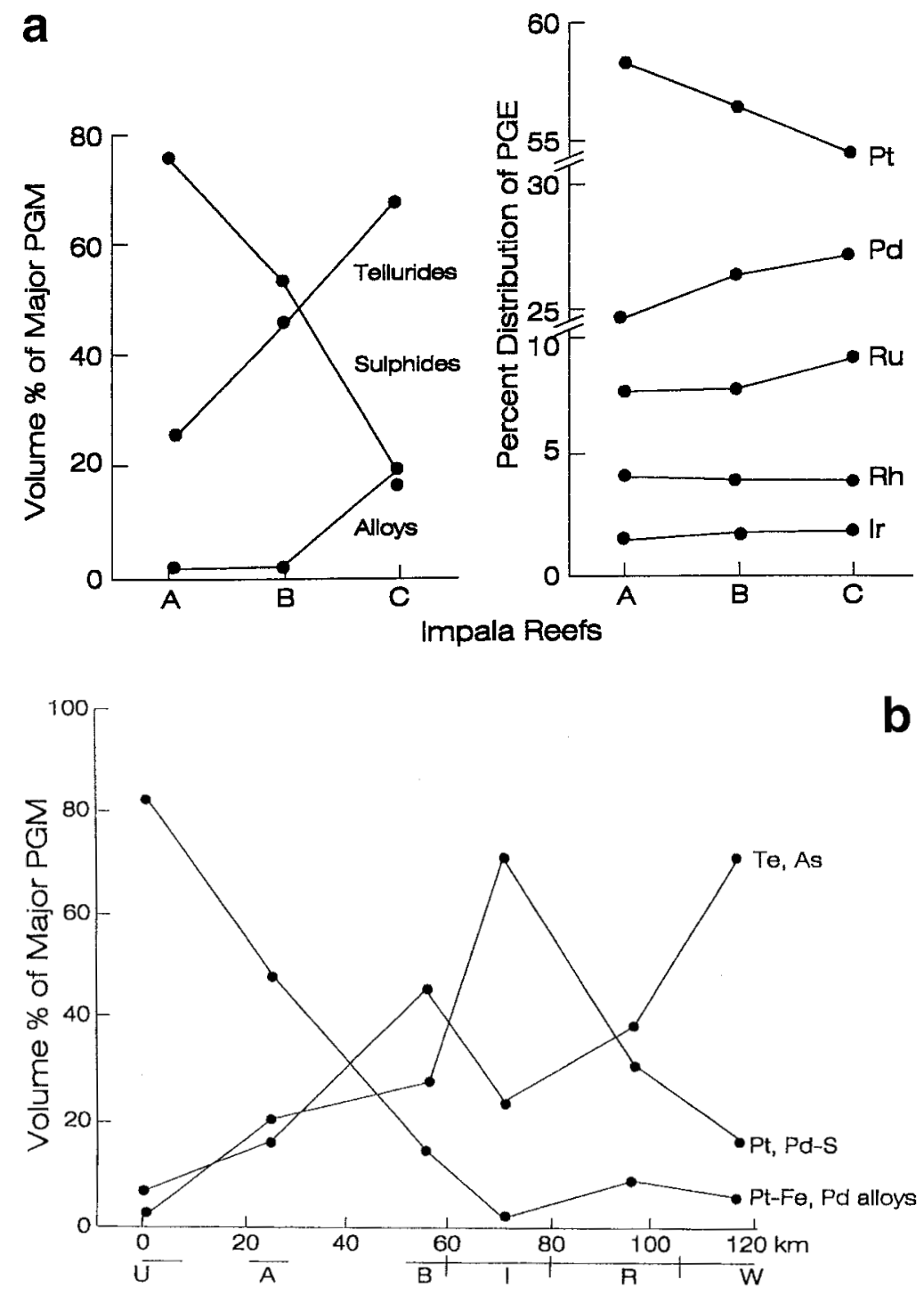

FIG. 11. a. Variation in PGM and PGE distribution from A, B and C reefs at the Impala mine. Data from an Impala mine unpublished report. The PGM distribution has been simplified into three groups: Pt and Pd sulfides, tellurides and arsenides, and alloys and metals, to simplify comparison with the regional variation in PGM, shown in Figure 11b.

1990, Lee 1996), although other PGM do occur (Tarkian \& Stumpfl 1975, Cabri et al. 1977a, b, c, Stumpfl \& Rucklidge 1982, Rudashevsky et al. 1992). No quantitative data on the distribution of PGE were ever presented while mining was ongoing and while significantly large samples were available for analysis, but a very few samples have recently been analyzed. McDonald et al. (1995) showed that these ores were dominated by $\mathrm{Pt}(90 \%)$, with minor $\mathrm{Pd}(6 \%)$ and $\mathrm{Au}$
(2\%). These chemical compositions and mineral assemblages are therefore consistent in indicating an extreme dominance of Pt over all other PGE. These compositions also are totally different from any of the other ores from the stratiform layers.

In proximity to these pipes (Fig. 13), the PGM in mineralized layers undergo significant changes, as documented by Peyerl (1982). The normal UG2 chromitite in the eastern Bushveld contains mainly PGE sulfides, 


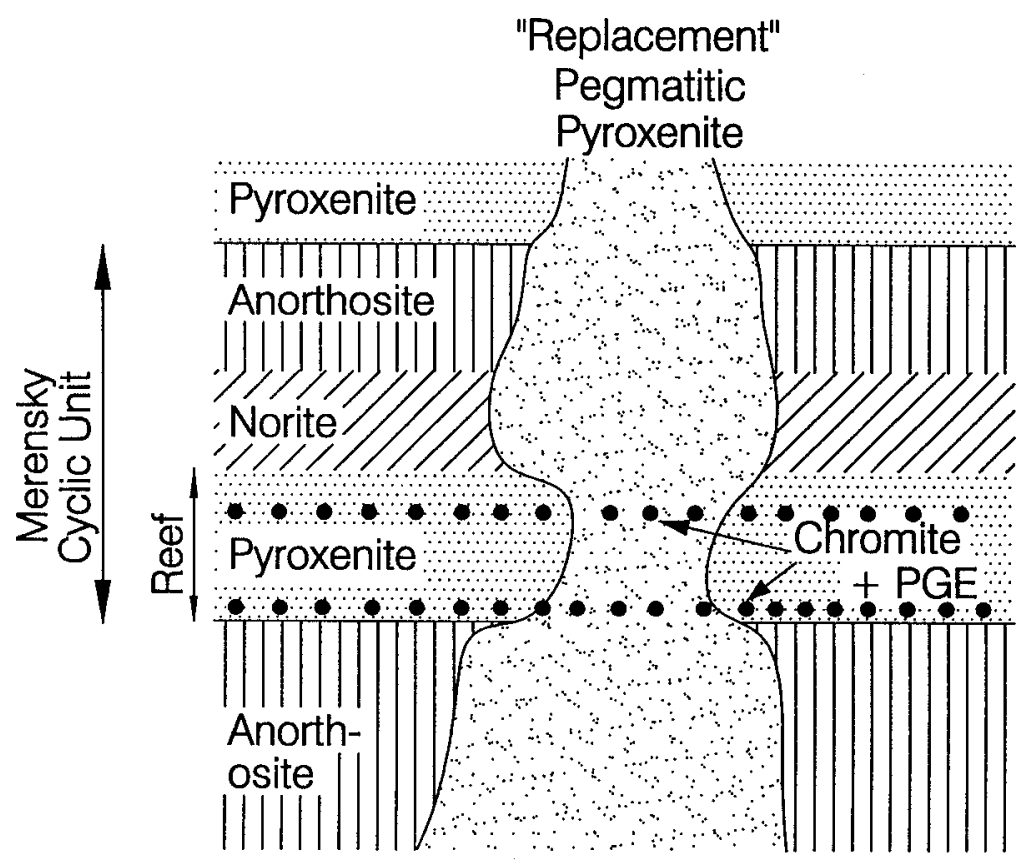

FIG. 12. Schematic representation of the observations regarding the preservation of PGE mineralization and chromite in their original location in the reef even after extensive replacement of the silicate host by a discordant ultramafic body (Viljoen et al. 1986b).

whereas within about $1 \mathrm{~km}$ of the Driekop pipe, they are almost totally alloys and tellurides. (Note that these data refer to the UG2; no information on the Merensky Reef in these sections was ever reported.) Actual PGE concentrations of the UG2 chromitite ore obtained by Peyerl in these intersections close to the Driekop pipe can now be published. In Figure 13, the PGE grades are shown as a function of distance from the pipe. For comparison, the average grade of the UG2 from one mine (Lebowa) and two intensively prospected areas (Maandagshoek and Winnaarshoek) also are shown. The five intersections of UG2 close to the pipe show a range of grades between 7 and $9 \mathrm{~g} / \mathrm{t}$. In one profile, only $\mathrm{Pt}, \mathrm{Pd}$ and $\mathrm{Rh}$ were sought, giving a content of $6.1 \mathrm{~g} / \mathrm{t}$. Assuming a typical value for $\mathrm{Ru}$ of $1.3 \mathrm{~g} / \mathrm{t}$, and allowing for minor $\mathrm{Os}$, $\mathrm{Ir}$ and $\mathrm{Au}$, the grade in this section would be about $7.5 \mathrm{~g} / \mathrm{t}$, in line with the other data. To the south, on the farm Maandagshoek, Gain (1986) quoted a grade of $9.5 \pm 1.8 \mathrm{~g} / \mathrm{t}$ over $0.55 \mathrm{~m}$, whereas to the north, grades of $7 \mathrm{~g} / \mathrm{t}$ over $0.87 \mathrm{~m}$ are given by Vermaak \& van der Merwe (1999), both from exploration surveys. The Lebowa mine some $40 \mathrm{~km}$ to the north has an average grade of $7.8 \mathrm{~g} / \mathrm{t}$ over $0.6 \mathrm{~m}$ (Hochreiter 2000). The slight variations in grade noted for these three properties (Maandagshoek, Driekop and Lebowa mine) become less significant when it is noted that with increasing grade, there is a decrease in thickness, and so the total PGE content of the UG2 chromitite layer can be considered essentially constant. The data for sections close to the pipe are totally consistent with the grades to the south and further to the north, suggesting no influence by the pipe.

Similarly, the distribution of the various PGE in sections from close to and further away from the pipe are quite constant (Fig. 13). There is one anomalous section $4 \mathrm{~km}$ from the pipe. No data for Ru are available for this intersection, which increases the apparent proportion of the other elements. However, the Pt:Pd ratio of this section is anomalous in being close to 1.5 , higher than typical values for the UG2 (Fig. 12). There is only one possible slight variation in grade of Au that may be attributable to the influence of the pipe. The grade of $\mathrm{Au}$ in the two profiles closest to the pipe is approximately double that from other sections and more distant samples. Apart from this variation in Au, the data in Figure 13 demonstrate that there is no enrichment or depletion in PGE or change in their relative proportions as a result of the emplacement of the pipe.

\section{DisCUSSION}

Hypotheses for the genesis of Merensky-Reef-style PGE mineralization fall into two categories. Some suggest that the ore minerals precipitated and accumulated 
from the magma overlying the instantaneous top of the crystal pile, in this instance the base of the Merensky cyclic unit (Campbell et al. 1983, Naldrett 1989), whereas others propose an origin by upward infiltration of a volatile-rich fluid (Vermaak 1976, Boudreau 1992, Boudreau \& Meurer 1999) or residual magma (Mathez et al. 1997) that scavenged PGE from the footwall succession. The former model can be considered a syngenetic process, whereas the latter is epigenetic. However, a process that blends the two models has been advocated, in which scavenging of the PGE from the footwall occurred by a fluid that then reacted with the magma at the crystal-magma interface to produce a primary sulfide precipitate (Willmore et al. 2000). In this model, the final process of concentration took place from the magma, but the source of the PGE was largely
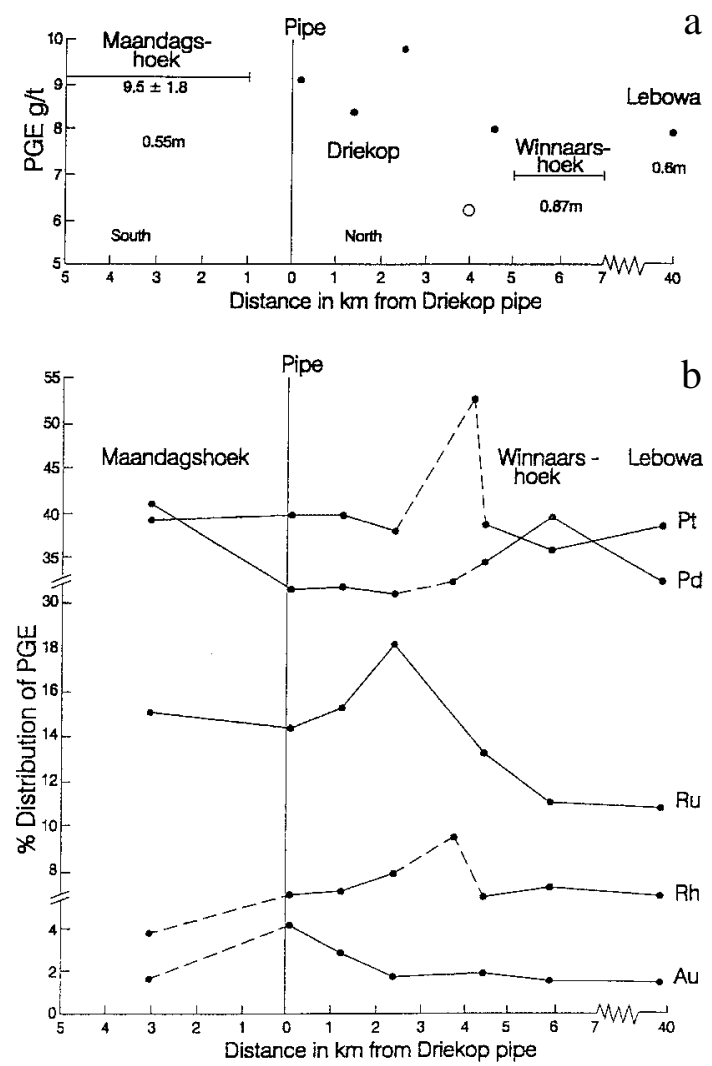

FIG. 13. Variation in PGE content of the UG2 chromitite from Maandagshoek in south, through Driekop pipe to Lebowa mine in the north (Fig. 1). a. Average grade and thickness of UG2 chromitite (open circle is for sample for which only $\mathrm{Pt}, \mathrm{Pd}$ and $\mathrm{Rh}$ contents available, hence lower total PGE content). Reef thicknesses are also indicated. Data are from Gain (1986), Table 1 and Peyerl (1982, but with previously unpublished data on PGE contents now made available). b. Distribution of the various PGE. the footwall. All these processes are eminently plausible, and determining which process might have been dominant is problematic, and has been debated extensively. Some additional comments are presented here.

The extreme variation in the proportions of the different groups of PGM, both on a regional scale (Fig. 9) and locally, associated with potholes (Fig. 11), is significant. Despite this variation, regional trends in PGE content and relative proportions of the PGE in the reefs are comparable. Likewise, on a local scale, both the A reef and $C$ reef (in a pothole) contain a comparable PGE content and relative proportions of PGE. Such constancy of PGE content and proportion, contrasting with the variation in PGM, suggests that the process that led ultimately to the observed mineralogy was not the same as that which produced the original mineralization. The formation of such a diverse PGM assemblage, from dominant PGE-bearing sulfides to alloys, suggests that local differences in $f\left(\mathrm{~S}_{2}\right)$ and $f\left(\mathrm{O}_{2}\right)$ must have prevailed during the re-equilibration processes. Such an interpretation implies the significant and laterally variable role of a fluid, as originally suggested by Kinloch (1982). However, the interaction of this fluid with the reefs has not demonstrably changed the abundances or relative proportions of the PGE.

A similar conclusion may be reached from the observation by Viljoen et al. (1986b), that the fluid phase responsible for the replacement pyroxenitic bodies cutting the Merensky Reef reacted extensively with the original silicate mineral assemblage, but had not moved either chromite or the earlier, stratiform PGE mineralization (Fig. 12). Such observations indicate that the fluids that influenced the final mineral assemblage and produced the discordant bodies did not remobilize the PGE.

The origin of dunite pipes and their mineralization has been debated. It has been suggested that the pipes are feeders of mineralization into the stratiform reefs (Schiffries 1982, Stumpfl \& Rucklidge 1982). Figure 13 shows that the PGE content and relative proportions do not appear to be influenced by proximity to a pipe, although the mineral assemblage was. The dominance of Pt over all other PGE in the pipes (Lee 1996) contrasts with the PGE distribution in the stratiform mineralization, and suggests that the two types of mineralization cannot be simply related, and any such inference about the role of fluids based on observations on mineralization in the pipes should not be applied to the stratiform orebodies.

The scavenging of the PGE from footwall cumulates involves a number of individually identifiable processes. Initially, the footwall cumulates had to be enriched in PGE, the process being attributed to formation of a minor amount of cumulus immiscible sulfide liquid (Mathez et al. 1997, Boudreau \& Meurer 1999, Maier $\&$ Barnes 1999). Those sulfides were then leached of some of their PGE by a vapor-rich (Willmore et al. 2000) or evolved silicate-rich (Mathez et al. 1997) fluid. 
This fluid either redissolved into a silicate magma, which triggered further PGE-rich sulfide immiscibility, or reacted with existing sulfide, low in PGE, in the precursor to the Merensky Reef ore. Each of these three processes ought to fractionate the PGE relative to each other. Such fractionation will depend upon relative values for the silicate liquid - sulfide liquid partition coefficients for the first stage. For the second stage, fractionation will depend upon the partitioning between solid or liquid sulfide and the fluid (either vapor or evolved hydrous magma). The third stage of fractionation will involve the reaction of this fluid with silicate magma or existing sulfide. Ballhaus \& Ryan (1995) and Ballhaus \& Sylvester (2000) emphasized the very similar relative proportions of the PGE within the Merensky Reef and proposed parental magmas to the Bushveld Complex. Such a similarity argues for minimal fractionation during the formation of the Merensky Reef relative to the magma. It would appear unlikely that the three separate processes identified above in the PGE scavenging model could have operated without fractionation among the PGE.

If the PGE were scavenged from the footwall and reprecipitated in the reef, there should be some correlation between the vertical section of cumulates processed and the total PGE content of reefs. The Rustenburg mine occurs in what is thought to be a trough, such that the reef here overlies the thickest footwall succession. From the base of the intrusion to the Merensky Reef, the sequence at the Rustenburg mine is $1800 \mathrm{~m}$, based on borehole information (Vermaak 1976). In contrast, the Western mine overlies a structural high and has a footwall succession of only $780 \mathrm{~m}$, based on the outcrop map of Davey (1992). The mineralized succession at the Rustenburg mine carries $8.5 \mathrm{~g} / \mathrm{t}$ over $40 \mathrm{~cm}$ or $6.9 \mathrm{~g} / \mathrm{t}$ over $90 \mathrm{~cm}$ mining width, and the Western mine, $5.6 \mathrm{~g} / \mathrm{t}$ over their standard mining width (Table 1). However, it is not just the PGE content of the Merensky Reef that should be considered in such a vertical summation. The content of PGE in the UG2 chromitite needs to be considered. At both the Rustenburg and Western mines, grades of $6.1 \mathrm{~g} / \mathrm{t}$ are reported, and the UG2 is slightly thicker at the Western compared to the Rustenburg mine. A more rigorous calculation of the PGE content of the entire succession would be desirable, but is not possible. Despite a difference of more than a factor of two in the vertical section available for PGE extraction at the two mines, the combined PGE contents of UG2 and Merensky reefs are not significantly different. Boudreau \& Meurer (1999) concluded that the longer the metasomatic front travels, the higher the resulting concentrations of the PGE. In view of the remarkable similarity in total PGE content, around the western limb especially (Table 1), the proposed metasomatic front would have to have risen comparable vertical distances despite the wide variation in total thickness of the footwall cumulates. Whereas the total PGE-scavenging ability of fluids cannot be quantified, the relatively constant
PGE content regardless of footwall thickness of the reef appears more consistent with derivation from a uniform thickness of supernatant magma.

One consequence of the chromatographic extraction model is that the different PGE should have become vertically segregated (Boudreau \& Meurer 1999) as a result of different partition-coefficients between sulfide and vapor. Such separation has been identified in the Munni Munni intrusion (Barnes 1993). Of two sufficiently detailed published sections through the Merensky Reef (Lee 1983, Barnes \& Maier 2002), neither shows a separation of the PGE, with maximum values for all known PGE and Au being coincident on a scale of the sampling length of $20 \mathrm{~cm}$ (Lee 1983) and $10 \mathrm{~cm}$ (Barnes \& Maier 2002).

The above discussions refer to abundances of PGE. However, if this vapor-refining model of Willmore $e t$ al. (2000) had operated, it should have influenced basemetal distribution. The $\mathrm{Cu}$ and $\mathrm{Ni}$ in the alleged primary sulfide in the footwall ought to have been variably partitioned into the fluid together with the PGE. When the fluid reacted with existing sulfide or dissolved in the magma to form the Merensky mineralization, the ensuing sulfide should have been enriched in these base metals as well as PGE. In a similar model, Mathez et al. (1997) stated that the residual silicate liquid percolating upward through the sulfide-bearing cumulates ought to have scavenged $\mathrm{Cu}, \mathrm{Ni}$ as well as the PGE, leading to enrichment of both base and precious metals. The Ni, $\mathrm{Cu}$ and $\mathrm{S}$ contents of the Merensky Reef have been quoted as 2377, 1115 and $5528 \mathrm{ppm}$, respectively (Vermaak 1976), which have been converted to yield a sulfide fraction of the Merensky Reef of $4.6 \% \mathrm{Cu}$ and $10.9 \% \mathrm{Ni}$ (Naldrett 1981). Such values are predictable for an immiscible sulfide liquid (Naldrett 1989). In the model of metasomatic refining, it is difficult to understand how the PGE were extensively enriched in the reef but $\mathrm{Cu}$ and $\mathrm{Ni}$ were not.

The ${ }^{187} \mathrm{Os} /{ }^{188} \mathrm{Os}$ values in the Bushveld Complex provide a useful fingerprint for the source of Os and, by inference, the other PGE. Hart \& Kinloch (1989) first presented initial ${ }^{187} \mathrm{Os} /{ }^{188} \mathrm{Os}$ values of $0.17-0.18$ on laurite grains from the Merensky Reef. Subsequently, Schoenberg et al. (1999) and McCandless et al. (1999) determined values of $0.11-0.15$ from all the chromitite layers below the Merensky Reef. In a model involving scavenging of Os and other PGE from the footwall succession and redeposition at the Merensky Reef, it would be expected that the Os isotopic ratio of laurite in the Merensky Reef would be some integrated value of that residing in the footwall. It has yet to be shown that these values for the chromitite layers are typical of the entire footwall sequence, and also that the source of all the other PGE is the same as for Os. However, the fact that the Os isotopic ratio for the Merensky Reef is significantly higher than for any sample studied from the footwall must be considered a challenge to the zone-refining hypothesis. 
In the PGE-concentration process proposed by Mathez et al. (1997), a volatile-rich residual magma was trapped beneath the anorthosite of the Merensky cyclic unit. The trapping was related to the different rate of ascent of residual magma through a density-stratified sequence of host rocks. Rapid ascent through a dense, pyroxene-rich host resulted in the ponding beneath lowdensity anorthosite through which ascent was slower. Specifically, the authors argued that an anorthosite layer $10 \mathrm{~m}$ thick would retard upward migration sufficiently that hydration melting and recrystallization would have occurred to produce the PGE-rich pegmatitic rocks of the Merensky cyclic unit. Relating the PGE mineralization to this process becomes problematic. The section for the Lebowa mine (Fig. 5), used for the study of Mathez et al. (1997), shows that the main mineralization occurs above, not within, the pegmatitic rocks. At the northern half of the Impala mine, there is no pegmatitic facies (Fig. 5), yet there is still PGE mineralization. Further, the significance of an adequate thickness of anorthosite to trap the residual magma must be questioned. As shown in Figure 3, many vertical sections of anorthosite over $10 \mathrm{~m}$ thick exist in the footwall to the Merensky Reef. None of these layers has an underlying pegmatitic layer or any PGE mineralization. Thus, the association of PGE with pegmatitic rocks is far from ubiquitous, and the uniqueness of the 10-m-thick anorthosite above the Merensky Reef, to act as a trap for residual magma, is invalid.

The above observations present a number of questions that need to be addressed in order to substantiate processes involving scavenging of the PGE from the footwall to the Merensky Reef.

The hypothesis of accumulation of PGE primarily from supernatant magma above the crystal-magma interface is largely influenced by the observation that the mineralization is stratiform, and has been considered to be a layer analogous to the silicate-dominant layers. In its original form, it was considered that the primary accumulating phase was an immiscible sulfide liquid (Campbell et al. 1983), that the PGE had sufficiently large partition-coefficients, and that a sufficiently large volume of magma was processed to produce the enormously high concentration of PGE in a small volume of sulfide (Naldrett 1989). Such a view was supported by the fact that the proportions of PGE in the reef are similar to what is proposed for the parental magma, as emphasized by Ballhaus \& Sylvester (2000). The presence of mineralization in the footwall anorthosite, where the reef is thin, and its absence where the reef is thick, were considered the result of downward percolation of dense sulfide liquid into unconsolidated anorthositic footwall (Cawthorn 1999b), as originally proposed by Wagner (1929).

An alternative view considers the reef to have formed by primary accumulation of PGE separately from the sulfide phase. The PGE may have formed clusters of metal ions (Tredoux et al. 1995) that may have been physically entrained (as distinct from being chemically dissolved) in the sulfide liquid (Barnes 1993). Alternatively, they may have formed as iron-PGE alloy or discrete PGE-dominant minerals (Merkle 1992, Brenan \& Andrews 2001, Gornostayev et al. 2001). Physical accumulation and fixation in the reef may have been aided by adherence to, and encapsulation by, chromite grains (Hiemstra 1985) or sulfide (Ballhaus \& Sylvester 2000). However, these metal clusters and minerals are dominated by Ru, Os and Ir, and if their accumulation was the major mechanisms of concentration, these elements would be enriched relative to $\mathrm{Pt}$ and $\mathrm{Pd}$, which is not markedly the case in the Merensky Reef.

A detailed study of the PGE distribution in the Merensky Reef by Barnes \& Maier (2002) has prompted a refinement to the above two suggestions. They argued that the distribution of PGE in the Merensky Reef is consistent with neither accumulation in sulfide liquid nor as discrete PGM alone. They therefore suggest that both processes had to have operated simultaneously, each process producing enrichment with different relative abundances of the different PGE. The constancy of the PGE proportions throughout all the mines demands that these two processes would have to have operated in exactly the same ratio everywhere, and to have been initiated and terminated simultaneously.

Several of these debates are based upon the relative significance of trace PGM, and the timing of their formation, specifically whether they can form directly from magma at high temperature. What is evident from this compilation is that the PGE proportions remain relatively constant across the reef regardless of the observed PGM. We concur with Ballhaus \& Ryan (1995) that the PGE-sulfide system re-equilibrated to low temperatures, and that observed PGM assemblages may not be reliable indicators of the original mechanisms of concentration of the PGE.

\section{Conclusions}

The grade of PGE over a mining width in the Merensky Reef is remarkably constant at about 5-7 g/t for the eastern and most of the western limb of the Bushveld Complex. Only in the northwestern portion of the western limb is there an area of distinctly higher grade, and in the southeast, an area of lower grade. Also, the relative proportions of the six PGE remain uniform over the entire strike-length, streching over $100 \mathrm{~km}$ in both limbs. Even in potholes and close to transgressive ultramafic pipes, both grade and relative proportions of PGE remain constant. In contrast, the nature of the PGM is highly variable. In the western limb, they range from alloy-dominant in the northwest to sulfide- and telluride-dominant in the southeast. Such variation occurs on a much smaller scale with a change from PGE sulfides in normal reef to alloy in potholes and near pipes. The constancy of levels of PGE seems to be a primary feature, and the final PGM assemblages are the result of 
slow cooling and exsolution, and response to local variations of conditions, such as $f\left(\mathbf{S}_{2}\right)$ in potholes and near pipes. The mineralized dunite pipes are dominated by Pt over all other PGE, and so are different from the layered orebodies. Thus, extrapolation of processes producing mineralization in the pipes to the stratiform deposits may not valid.

The total thickness of the footwall succession to the Merensky Reef varies by a factor of two between the Rustenburg and Western mines, yet the total PGE grades in Merensky and UG2 chromitite do not vary significantly. Such a relationship argues against the hypotheses that envisage scavenging of footwall cumulates of their PGE and redeposition at appropriate layers in the sequence.

The initial ${ }^{187} \mathrm{Os} /{ }^{188} \mathrm{Os}$ values for laurite grains from the Merensky Reef differ from values in the entire footwall succession, a distinction not expected if the Os, and by inference the other PGE, were largely extracted from the footwall rocks.

In order to explain the distribution of the PGE in the Merensky Reef, it has been suggested that both immiscible sulfide liquid and a PGE-rich phase (alloy or sulfide) must coprecipitate. Whether such coprecipitation is possible, and whether they can co-accumulate in exactly the same proportions everywhere to yield the constant patterns of PGE distribution, remain to be demonstrated.

\section{ACKNOWLEDGEMENTS}

The support of Anglo Platinum, Impala Platinum, Lonmin and the National Research Foundation to RGC, and permission to publish these data presented here by Anglo American Platinum and Impala Platinum Mines, are gratefully acknowledged. Thorough reviews by Alan Boudreau and an anonymous reviewer are appreciated. It is with great pleasure that we dedicate this contribution to Dr. Louis J. Cabri, a graduate of the University of the Witwatersrand.

\section{REFERENCES}

Ballhaus, C. \& Ryan, C.G. (1995): Platinum-group elements in the Merensky Reef. I. PGE in solid solution in base metal sulfides and the down-temperature equilibration history of Merensky ores. Contrib. Mineral. Petrol. 122, 241-251.

\& Sylvester, P. (2000): Noble metal enrichment processes in the Merensky Reef, Bushveld Complex. $J$. Petrol. 41, 545-561.

Barnes, S.-J. \& MAIER, W.D. (2002): Platinum-group elements and microstructures of normal Merensky Reef from Impala Platinum Mines, Bushveld Complex. J. Petrol. 43, 171-198.

BARNES, S.J. (1993): Partitioning of platinum group elements and gold between silicate and sulphide magmas in the
Munni Munni Complex, Western Australia. Geochim. Cosmochim. Acta 57, 1277-1290.

BOUDREAU, A.E. (1992): Volatile fluid overpressure in layered intrusions and the formation of potholes. Aust. J. Earth Sci. 39, 277-287.

\& Meurer, W.P. (1999): Chromatographic separation of the platinum-group elements, gold, base metals and sulfur during degassing of a compacting and solidifying igneous crystal pile. Contrib. Mineral. Petrol. 134, 174-185.

Brenan, J.M. \& Andrews, D. (2001): High-temperature stability of laurite and Ru-Os-Ir alloy and their role in PGE fractionation in mafic magmas. Can. Mineral. 39, 341-360.

BrynaRd, H.J., De Villiers, J.P.R. \& VilJoEn, E.A. (1976): A mineralogical investigation of the Merensky Reef at the Western platinum mine, near Marikana, South Africa. Econ. Geol. 71, 1299-1307.

Cabri, L.J., Laflamme, J.H.G. \& Stewart, J.M. (1977a): Platinum-group minerals from Onverwacht. II. Platarsite, a new sulfarsenide of platinum. Can. Mineral. 15, 385-388.

Rosenzweig, A. \& Pinch, W.W. (1977b): Platinumgroup minerals from Onverwacht. I. $\mathrm{Pt}-\mathrm{Fe}-\mathrm{Cu}-\mathrm{Ni}$ alloys. Can. Mineral. 15, 380-384.

Stewart, J.M., LAFlamme, J.H.G. \& SZYMAŃSKI, J.T. (1977c): Platinum-group minerals from Onverwacht. III. Genkinite, $(\mathrm{Pt}, \mathrm{Pd})_{4} \mathrm{Sb}_{3}$, a new mineral. Can. Mineral. 15, 389-392.

CAmpbell, I.H., NAldRetT, A.J. \& BARnes, S.J. (1983): A model for the origin of the platinum-rich sulfide horizons in the Bushveld and Stillwater complexes. J. Petrol. 24, 133-165.

Carr, H.W., Groves, D.I. \& Cawthorn, R.G. (1994): The importance of synmagmatic deformation in the formation of the Merensky Reef potholes in the Bushveld Complex. Econ. Geol. 89, 1398-1410.

CAWTHORn, R.G. (1999a): The platinum and palladium resources of the Bushveld Complex. S. Afr. J. Sci. 95, 481489.

(1999b): Permeability of the footwall cumulates to the Merensky Reef, Bushveld Complex. S. Afr. J. Geol. 102, 293-302.

\& BARRY, S.D. (1992): The role of intercumulus residua in the formation of pegmatoid associated with the UG2 chromitite, Bushveld Complex. Aust. J. Earth Sci. 39, 263-276.

DAVEY, S.R. (1992): Lateral variations within the upper Critical Zone of the Bushveld Complex on the farm Rooikoppies 297JQ, Marikana, South Africa. S. Afr. J Geol. 95, 141-149.

Eales, H.V., Botha, W.J., Hattingh, P.J., De KleRK, W.J., MAIER, W.D. \& Odgers, A.T. (1993): The mafic rocks of 
the Bushveld Complex: a review of emplacement and crystallization history, and mineralization, in the light of recent data. J. Afr. Earth Sci. 16, 121-142.

Edwards, A.M. \& Silk, M.H. (1987): Platinum in South Africa. Council Mineral Technology (Randburg, South Africa), Special Publication 12.

GAIN, S.B. (1985): The geologic setting of the platiniferous UG2 chromitite layer on Maandagshoek, eastern Bushveld Complex. Econ. Geol. 80, 925-943.

(1986): The upper group chromitite layers at Maandagshoek, eastern Bushveld Complex. In Mineral Deposits of Southern Africa 2 (C.R. Anhaeusser \& S. Maske, eds.). Geological Society of South Africa, Johannesburg, South Africa (1197-1208).

Gornostayev, S.S., Ohnenstetter, M., Neziraj, A., Ohnenstetter, D., LaAjoki, K.V.O., Popovchenko, S.E.\& KornienKo, P.K. (2001): New occurrence of anduoite $(\mathrm{Ru}, \mathrm{Os}) \mathrm{As}_{2}$ from chromite deposits of Ukraine and Albania. Can. Mineral. 39, 591-606.

HAHN, U.F. \& OvENDALE, B. (1994): UG2 chromitite layer potholes at Wildebeestfontein north mine, Impala Platinum Limited. Proc. $15^{\text {th }}$ CMMI Congress, S. Afr. Inst. Mining Metall., 195-200.

HART, S.R. \& Kinloch, E.D. (1989): Osmium isotope systematics in Witwatersrand and Bushveld ore deposits. Econ. Geol. 84, 1651-1655.

Hiemstra, S.A. (1985): The distribution of some platinum group elements in the UG2 chromitite layer of the Bushveld Complex. Econ. Geol. 80, 944-957.

(1986): The distribution of chalcophile and platinumgroup elements in the UG2 chromitite layer of the Bushveld Complex. Econ. Geol. 81, 1080-1086.

Hochreiter, R. (2000): Platinum Producers. Barnard, Jacobs and Mellet, Johannesburg, South Africa.

KINLOCH, E.D. (1982): Regional trends in the platinum-group mineralogy of the Critical Zone of the Bushveld Complex, South Africa. Econ. Geol. 77, 1328-1347.

\& PeyerL, W. (1990): Platinum-group minerals in various rock types of the Merensky Reef: genetic implications. Econ. Geol. 85, 537-555.

LEE, C.A. (1983): Trace and platinum-group element geochemistry and the development of the Merensky Unit of the western Bushveld Complex. Mineral. Deposita 18, 173-190.

(1996): A review of mineralization in the Bushveld Complex and some other layered intrusions. In Layered Intrusions (R.G. Cawthorn, ed.) Elsevier, Amsterdam, The Netherlands (103-145).

\& PARRY, S.J. (1988): Platinum-group element geochemistry of the Lower and Middle Group chromitites of the eastern Bushveld Complex. Econ. Geol. 83, 1127-1139.
\& Tredoux, M. (1986): Platinum-group element abundances in the Lower and Lower Critical zones of the Bushveld Complex. Econ. Geol. 81, 1087-1095.

Leeb-Du Toit, A. (1986): The Impala Platinum Mines. In Mineral Deposits of Southern Africa 2 (C.R. Anhaeusser \& S. Maske, eds.). Geol. Soc. S. Afr., Johannesburg, South Africa (1091-1106).

Lomberg, K.G., Martin, E.S., Patterson, M.A. \& Venter, J.E. (1999): The morphology of potholes in the UG2 Chromitite layer and Merensky Reef (pothole reef facies) at Union Section, Rustenburg Platinum Mines. S. Afr. J. Geol. 102, 209-220.

MAier, W.D. \& BARnes, S.-J. (1999): Platinum-group elements in silicate rocks of the Lower, Critical and Main zones at Union Section, western Bushveld Complex. $J$. Petrol. 40, 1647-1671.

MAthez, E.A., Hunter, R.H. \& Kinzler, R. (1997): Petrologic evolution of partially molten cumulate: the Atok section of the Bushveld Complex. Contrib. Mineral. Petrol. 129, 2034.

McCandless, T.E., Ruiz, J., Adair, B.I. \& Freydier, C. (1999): $\mathrm{Re}-\mathrm{Os}$ isotope and $\mathrm{Pd} / \mathrm{Ru}$ variations in chromitites from the Critical Zone, Bushveld Complex, South Africa. Geochim. Cosmochim. Acta 63, 911-923.

McDonald, I., Vaughan, D.J. \& Tredoux, M. (1995): Platinum mineralization in quartz veins near Naboomspruit, central Transvaal. S. Afr. J. Geol. 98, 168-175.

McLaren, C.H. \& De Villiers, J.P.R. (1982): The platinumgroup chemistry and mineralogy of the UG2 chromitite layer of the Bushveld Complex. Econ. Geol. 77, 1348-1366.

Merkle, R.K.W. (1992): Platinum-group minerals in the middle group of chromitite layers at Marikana, western Bushveld Complex: indications for collection mechanisms and post-magmatic modification. Can. J. Earth Sci. 29, 209-221.

Mossam, R.J. (1986): The Atok platinum mine. In Mineral Deposits of Southern Africa 2 (C.R. Anhaeusser \& S. Maske, eds.). Geological Society of South Africa, Johannesburg, South Africa (1143-1154).

Mostert, A.B., Hofmeyr, P.K. \& Potgieter, G.A. (1982): The platinum-group mineralogy of the Merensky Reef at the Impala platinum mines, Bophuthatswana. Econ. Geol. 77, 1385-1394.

NALDRETT, A.J. (1981): Platinum-group element deposits. In Platinum-Group Elements: Mineralogy, Geology, Recovery. (L.J. Cabri, ed.). Can. Inst. Mining Metall., Spec. Vol. 23, 197-232.

(1989): Stratiform PGE deposits in layered intrusions. Rev. Econ. Geol. 4, 135-166.

\& CABRI, L.J. (1976): Ultramafic and related mafic rocks: their classification and genesis with special reference 
to the concentration of nickel sulfides and platinum-group elements. Econ. Geol. 71, 1131-1158.

Penberthy, C.J. \& Merkle, R.K.W. (1999): Lateral variations in the platinum-group element content and mineralogy of the UG2 chromitite layer, Bushveld Complex. S. Afr. J. Geol. 102, 240-250.

Oosthuyzen, E.J. \& Merkle, R.K.W. (2000): The recovery of platinum-group elements from the UG-2 chromitite, Bushveld Complex - a mineralogical perspective. Mineral. Petrol. 68, 213-222.

Peyerl, W. (1982): The influence of the Driekop dunite pipe on the platinum-group mineralogy of the UG2 chromitite in its vicinity. Econ. Geol. 77, 1432-1438.

Rudashevsky, N.S., Avontsev, S.N. \& Dneprovskaya, M.B. (1992): Evolution of PGE mineralization in hortonolitic dunites of the Mooihoek and Onverwacht pipes, Bushveld Complex. Mineral. Petrol. 47, 37-54.

SCHIFFRIES, C.M. (1982): The petrogenesis of a platiniferous dunite pipe in the Bushveld Complex: infiltration metasomatism by a chloride solution. Econ. Geol. 77, $1439-1453$

Schoenberg, R., Kruger, F.J., Nagler, T.F., Meisel, T. \& KRAMERS, J.D. (1999): PGE enrichment in chromitite layers and the Merensky Reef of the western Bushveld Complex: a Re-Os and Rb-Sr isotope study. Earth Planet. Sci. Lett. 172, 49-64.

Schouwstra, R.P., Kinloch, E.D. \& LeE, C.A. (2000): A short review of the Bushveld Complex. Platinum Minerals Rev. 44, 33-39.

Scoon, R.N. \& TEIGLER, B. (1994): Platinum-group element mineralization in the Critical Zone of the western Bushveld Complex. 1. Sulfide-poor chromitites below the UG2. Econ. Geol. 89, 1094-1121.

Stumpfl, E.F. \& RucKlidge, J.C. (1982): The platiniferous pipes of the eastern Bushveld. Econ. Geol. 77, 1419-1431.

TARKIAN, M. \& STUMPFL, E.F. (1975): Platinum mineralogy of the Driekop mine, South Africa. Mineral. Deposita 10, 7185 .

Tredoux, M., Lindsay, N.M., Davies, G. \& McDonald, I. (1995): The fractionation of platinum-group elements in magmatic systems with the suggestion of a novel causal mechanism. S. Afr. J. Geol. 98, 157-167.

VAn Der Merwe, M.J. (1976): The layered sequence of the Potgietersrus limb of the Bushveld Complex. Econ. Geol. 71, 1337-1351.

VermaAK, C.F. (1970): The geology of the lower portion of the Bushveld Complex and its relationship to the floor rocks in the area west of the Pilanesberg, Western Transvaal. Geol. Soc. S. Afr., Spec. Publ. 1, 242-265.
(1976): The Merensky Reef - thoughts on its environment and genesis. Econ. Geol. 71, 1270-1298.

(1995). The Platinum-Group Metals - a Global Perspective. Council for Mineral Technology, Randburg, South Africa.

\& HendRIKs, L.P. (1976): A review of the mineralogy of the Merensky Reef, with specific reference to new data on the precious metal mineralogy. Econ. Geol. 71, 1244-1269.

\& Van Der Merwe, M.J. (1999): The Platinum Mines and Deposits of the Bushveld Complex, South Africa. Mintek, Randburg, South Africa.

VilJoen, M.J. (1999): The nature and origin of the Merensky Reef of the western Bushveld Complex based on geological facies and geophysical data. S. Afr. J. Geol. 102, 221-239.

De Klerk, W.J., Coetzer, P.M., Hatch, N.P., KINLOCH, E.D. \& PeYERL, W. (1986a): The Union Section of Rustenburg Platinum Mines Limited, with reference to the Merensky Reef. In Mineral Deposits of Southern Africa 2 (C.R. Anhaeusser \& S. Maske, eds.). Geological Society of South Africa, Johannesburg, South Africa (1061-1090).

\& Schurmann, L.W. (1998): Platinum-group metals. In The Mineral Resources of South Africa (M.C.G. Wilson \& C.R. Anhaeusser, eds). Council for Geoscience, Pretoria, South Africa (532-568).

Theron, J., Underwood, B., Walters, B.M., Weaver, J. \& Peyerl, W. (1986b): The Amandelbult section of Rustenburg Platinum Mines Limited, with reference to the Merensky Reef. In Mineral Deposits of Southern Africa 2 (C.R. Anhaeusser \& S. Maske, eds.). Geological Society of South Africa, Johannesburg, South Africa (1041-1060).

VIRING, R.G. \& CowEll, M.W. (1999): The Merensky Reef on Northam Platinum Mine Limited. S. Afr. J. Geol. 102, 192208.

Von Gruenewaldt, G., Hatton, C.J., Merkle, R.K.W. \& GAIN, S.B. (1986): Platinum-group element - chromitite associations in cumulates of the Bushveld Complex. Econ. Geol. 81, 1067-1079.

\& MERKLE, R.K.W. (1995): Platinum group element proportions in chromitites of the Bushveld Complex: implications for fractionation and magma mixing models. J. Afr. Earth Sci. 21, 615-632.

WAgner, P.A. (1929): The Platinum Deposits and Mines of South Africa. Oliver \& Boyd, Edinburgh, U.K.

White, J.A. (1994): The Potgietersrus project: geology and exploration history. In Proc. 15th CMMI Congress. S. Afr. Inst. Mining \& Metallurgy, Johannesburg, South Africa (173-182). 
Willmore, C.C., Boudreau, A.E. \& Kruger, F.J. (2000): The halogen geochemistry of the Bushveld Complex, Republic of South Africa: implications for chalcophile element distribution in the Lower and Critical zones. J. Petrol. 41, 1517-1539.
Received February 11, 2001, revised manuscript accepted November 21, 2001. 